Брич В.В., Грига М.М.

\title{
Стан підготовки фахівців 3 фізичної терапії/реабілітації, які займаються практичною діяльністю, до забезпечення комплексної реабілітації населення
}

\author{
ДВНЗ «Ужгородський національний університет», м. Ужгород, Україна
}

valeria.bruch@uzhnu.edu.ua, hruhamasha@gmail.com

\author{
Брич В.В., Грига М.М. \\ Состояние подготовки специалистов по физической \\ терапии/реабилитации, занимающихся практической \\ деятельностью, к обеспечению комплексной \\ реабилитации целевых групп населения \\ ГВУЗ «Ужгородский национальный университет», \\ г. Ужгород, Украина
}

Brych V.V., Hryha M.M.

Preparation level of practicing specialists in the field of physical therapy/rehabilitation to provide comprehensive rehabilitation of target population groups SU "Uzhhorod national university", Uzhhorod, Ukraine

\section{Вступ}

В Україні в галузі охорони здоров'я все більше стверджується реабілітаційний напрям, головним завданням якого $є$ етапне та комплексне відновлення здоров'я. Значна роль у цьому процесі належить фізичній реабілітації, яка направлена на максимальне відновлення функціональних можливостей організму людини, зокрема усунення рухових дисфункцій, після перенесених травм чи захворювань, прискорення відновлення функцій органів i систем, тренування i загартовування організму, повернення до працездатності, зменшення ймовірності інвалідності [1].

При підготовці майбутніх фахівців 3 фізичної терапії та ерготерапії обов'язковим $є$ питання: якими професійними компетенціями має володіти фахівець для здійснення ефективних дій у професійній області та сприяння максимальному відновленню функціональних можливостей пацієнтів. Сьогодні абсолютно визнана соціальна та державна потреба у підготовці вищими навчальними закладами фахівців 3 фізичної терапії 3 повноцінно розвиненими особистісними, вольовими та професійними якостями, про що свідчать нормативноправові акти Міністерства охорони здоров'я та Міністерства освіти і науки України [2]. Чітко завдання, обов'язки та знання фізичного терапевта визначені у пункті 27 підрозділу «Інші професіонали в галузі медицини» розділу «Професіонали», асистента фізичного терапевта - у пункті 55 розділу «Фахівці» довідника кваліфікаційних характеристик професій працівників (випуск 78 «Охорона здоров'я», зі змінами, визначеними наказом МО3 України від 13.12.2018 № 2331). При цьому новий стандарт вищої освіти за спеціальністю «фізична терапія, ерготерапія» галузі знань 22 «охорона здоров'я» затверджений тільки для першого бакалаврського рівня вищої освіти (наказ МОН України від 19.12.2008 № 1419).
У вище вказаному довіднику кваліфікаційних характеристик професій працівників також визначені характеристики лікаря 3 фізичної та реабілітаційної медицини, який організовує, очолює та забезпечує координацію виконання повного реабілітаційного циклу [3].

Одним з найважливіших питань розбудови сучасної системи фізичної реабілітації $\epsilon$ підготовка і пошук фахівців, які $б$ мали достатні рівні теоретичної та практичної підготовки для проведення самостійних обстежень, вибору комплексу реабілітаційних методик чи розробки комплексу для конкретного пацієнта. При цьому під практичною підготовкою розуміється будь-яка роль, у якій фахівець набуває навичок застосування своїх умінь і знань як фізичного терапевта. Практична підготовка не обмежується наданням прямої клінічної допомоги. Сюди також входить робота щодо прямого неклінічного зв'язку з пацієнтами/клієнтами; робота в управлінні, адміністрації, освіті, в науково-дослідницькій, консультативній, регуляторній ролі, будь-якій іншій ролі, що впливає на ефективне надання послуг за професією та/або використання професійних навичок [4].

Система охорони здоров'я в нашій країні потребує кваліфіковано підготовлені кадри, які здатні реалізувати сучасні комплексні оздоровчо-реабілітаційні технології у лікувально-профілактичних, санаторно-курортних і спортивно-оздоровчих закладах всіх форм власності. Саме тому, актуальним $є$ дослідження рівнів теоретичної i практичної підготовки тих фахівців, що вже займаються професійною діяльністю у сфері фізичної терапіі/ реабілітації.

Мета роботи: проаналізувати рівні теоретичної i практичної підготовки фізичних терапевтів та реабілітологів, які здійснюють професійну діяльність, для забезпечення комплексної реабілітації цільових груп населення. 


\section{Об'скт і методи дослідження}

Під час дослідження було використано такі методи: системний підхід і системний аналіз; соціологічний - для отримання інформації шляхом письмового опитування респондентів; статистичний метод - для математичної обробки отриманих даних. Соціологічне дослідження охопило 20 фахівців 3 фізичної терапії та фізичної реабілітації (кількість респондентів обумовлена малою чисельністю генеральної сукупності цільової групи в регіоні), і проводилося 3 використанням спеціально розробленого опитувальника, який включав: особисті дані; питання зайнятості та освіти; питання щодо підвищення кваліфікації; питання самооцінки власного рівня теоретичної та практичної підготовки для забезпечення комплексної реабілітації цільових груп; питання забезпечення та організації професійної діяльності.

\section{Результати дослідження та їх обговорення}

За освітою більшість опитаних (70\%) здобули освітній ступінь «магістр», 20\% - «бакалавр», 10\% «спеціаліст». Загальний стаж роботи у сфері фізичної реабілітації склав до 2 років включно у $80 \%$ респондентів, 3-5 років - у $20 \%$ учасників опитування. У результаті соціологічного дослідження, проведеного серед практикуючих фізичних терапевтів та фізичних реабілітологів, отримані результати щодо самооцінки власного рівня теоретичної підготовки для забезпечення комплексної реабілітації цільових груп населення, представлених на діаграмі (рис. 1).
3 особливостей реабілітації в амбулаторних умовах людей похилого віку

3 особливостей реабілітації в амбулаторних умовах осіб з інвалідністю

3 особливостей реабілітації в амбулаторних умовах дітей

Після перенесених оперативних втручань на різних органах:

Пацієнтів із різними видами залежностей (тютюнова,алкогольна, наркотична):

Після травм органів руху

При хворобах кістково-м’язової системи

При захворюваннях органів травлення

При захворюваннях органів дихання

При захворюваннях системи кровообігу

При хворобах центральної нервової системи

При захворюваннях периферичної нервової системи

в цілому

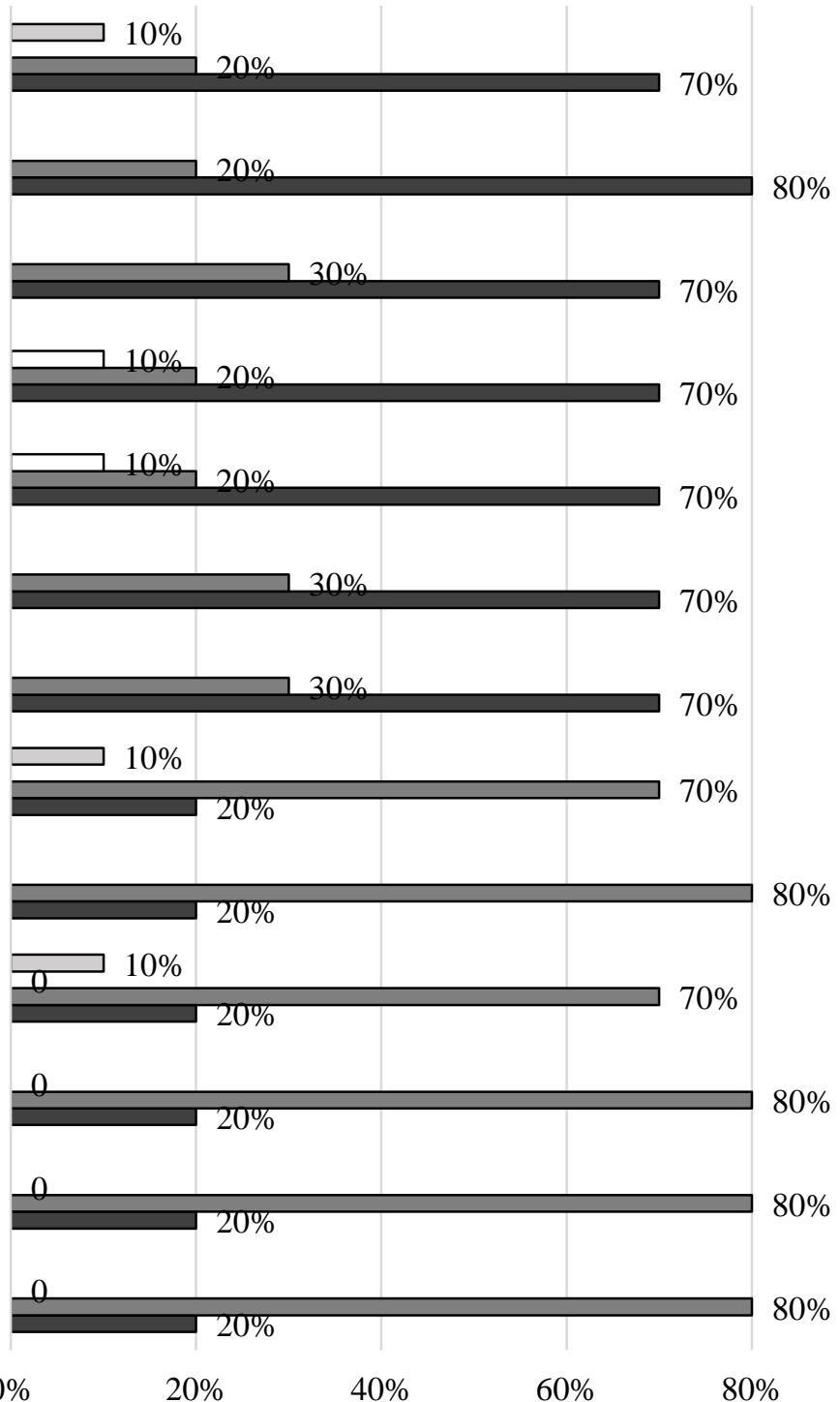

$100 \%$

口не можу визначитись $\quad$ 口більш недостатній, ніж достатній $\quad$ 口більш достатній, ніж недостатній $\quad$ достатній

Рис. 1. Розподіл відповідей респондентів щодо самооцінки власного рівня теоретичної підготовки для забезпечення комплексної реабілітації 
У результаті дослідження встановлено, що тільки $20 \%$ всіх опитаних фахівців оцінили власний рівень теоретичної підготовки 3 забезпечення комплексної реабілітації в цілому як достатній. Натомість, більша частина $(80 \%)$ визначили його як більш достатній, ніж недостатній.

Визначено, що найбільша кількість респондентів $(80 \%)$ як достатній оцінили власний теоретичний рівень підготовки 3 особливостей реабілітації осіб в амбулаторних умовах осіб з інвалідністю.

Встановлено, що 70\% опитаних фахівців оцінили власний рівень теоретичної підготовки як достатній в таких напрямках: забезпечення реабілітації при хворобах кістково-м'язової системи, травмах, пацієнтів з різними видами залежностей, після перенесених оперативних втручань на різних органах, особливостей реабілітації дітей та людей похилого віку в амбулаторних умовах. Слід зазначити, що по 10\% респондентів зазначили, що рівень теоретичної підготовки більш недостатній, ніж достатній, у них у питаннях надання послуг реабілітації пацієнтам
3 різними видами залежностей та пацієнтів після проведених оперативних втручань на різних органах.

Тільки по 20\% практикуючих фізичних терапевтів та реабілітологів оцінили власний рівень теоретичної підготовки з питань забезпечення комплексної реабілітації як достатній в таких напрямках: при хворобах центральної та периферичної нервової систем, серцево-судинної системи, органів дихання та органів травлення. В той же час, переважна більшість $(80 \%)$ визначила вказаний рівень як більш достатній, ніж недостатній, у питаннях реабілітації при захворюваннях центральної та периферичної нервових систем, хворобах органів дихання; та $70 \%$ респондентів - у питаннях реабілітації при хворобах серцево-судинної системи та органів травлення.

Відмінними від результатів самооцінки опитаними фахівцями власної теоретичної підготовки для забезпечення комплексної реабілітації, виявились результати їх самооцінки практичної підготовки, представлені на рисунку 2.

3 особливостей реабілітації в амбулаторних умовах людей похилого віку

3 особливостей реабілітації в амбулаторних умовах осіб з інвалідністю

3 особливостей реабілітації в амбулаторних умовах дітей

Після перенесених оперативних втручань на різних органах:

Пацієнтів із різними видами залежностей (тютюнова,алкогольна, наркотична):

Після травм органів руху

При хворобах кістково-м’язової системи

При захворюваннях органів травлення

При захворюваннях органів дихання

При захворюваннях системи кровообігу

При хворобах центральної нервової системи

При захворюваннях периферичної нервової системи

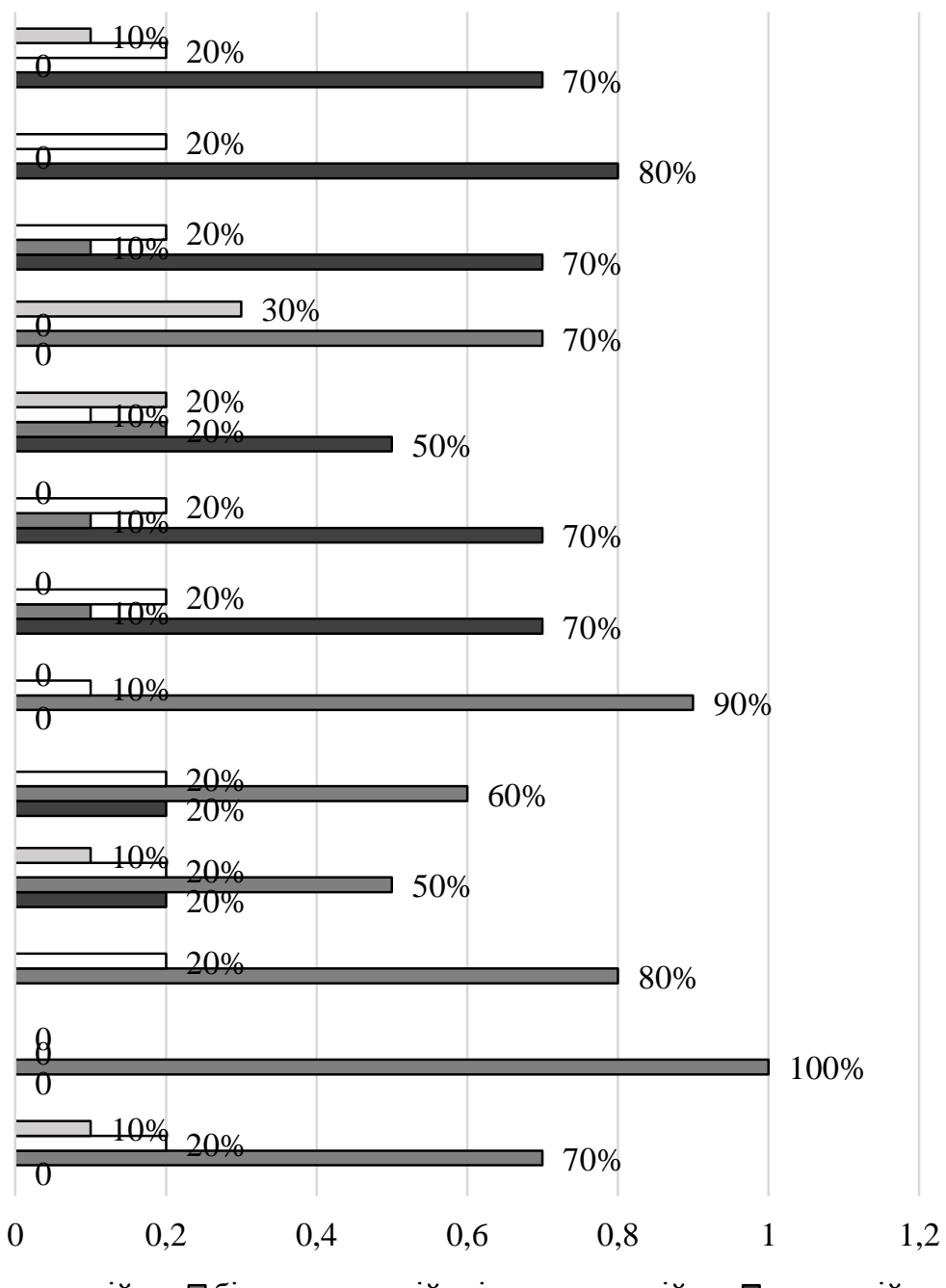

口недостатній $\quad \square$ більш недостатній, ніж достатній $\quad \square$ більш достатній, ніж недостатній $\quad \square$ достатній

Рис. 2. Розподіл відповідей респондентів щодо самооцінки власного рівня практичної підготовки для забезпечення комплексної реабілітації 
Так, повністю достатнім рівень практичної підготовки для забезпечення комплексної реабілітації в цілому не вказав жоден респондент. Більшість (70\%) визначила цей рівень як більш достатній, ніж недостатній, $20 \%$ респондентів вказали, що він більш недостатній, ніж достатній, а 10\% зазначили, що він не достатній.

У той же час абсолютно всі опитані респонденти $(100 \%)$ визначили власний рівень практичної підготовки 3 питань комплексної реабілітації при захворюваннях периферичної нервової системи як більш достатній, ніж недостатній. Що стосується практичної підготовки до забезпечення комплексної реабілітації при хворобах центральної нервової системи, то переважна більшість $(80 \%)$ визначили іiі рівень як більш достатній, ніж недостатній, а 20\% - як більш недостатній, як достатній.

Тільки п'ята частина опитаних $(20 \%)$ вказали на достатній рівень практичної підготовки 3 вказаного питання, половина респондентів вказали на більш достатній, ніж недостатній, 20\% - на більш недостатній, ніж достатній, а 10\% респондентів зазначили, що їх рівень практичної підготовки щодо забезпечення комплексної реабілітації при захворюваннях системи кровообігу недостатній.

На нашу думку, слід узагальнити, що певна частка респондентів вказала на недостатній рівень практичної підготовки в цілому та в окремих 4 запропонованих сферах: особливостей реабілітації в амбулаторних умовах людей похилого віку (10\%), пацієнтів після перенесених оперативних втручань на різних органах (30\%) та пацієнтів 3 різними видами залежностей (тютюнової, алкогольної, наркотичної) (20\%) та при захворюваннях системи кровообігу (10\%) (рис. 3).
3 особливостей реабілітації в амбулаторних умовах людей похилого віку

Після перенесених оперативних втручань на різних органах

Паціенти з різними видами залежності (тютюнова, алкогольна, наркотична)

При захворюваннях системи кровообігу

В цілому

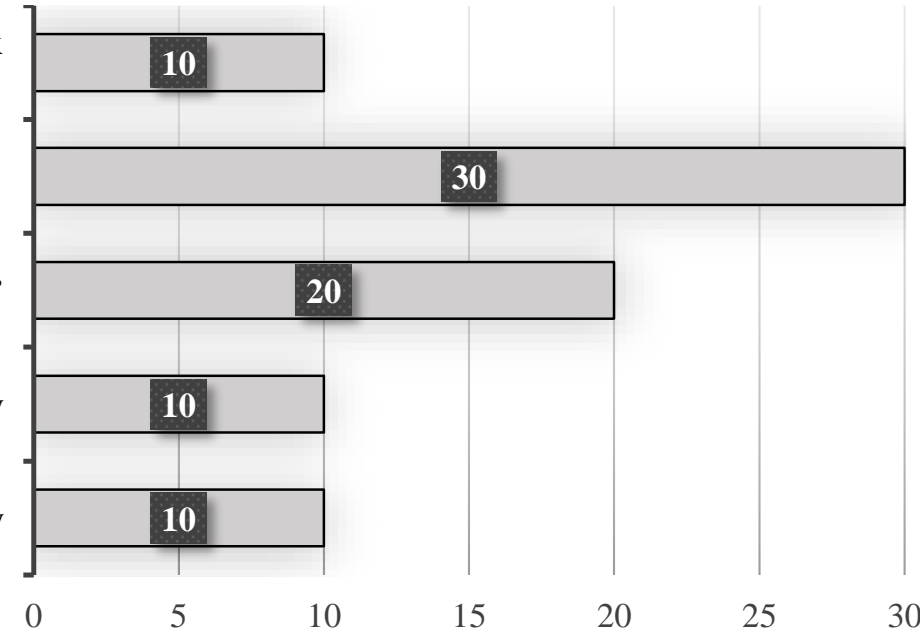

Рис. 3. Розподіл відповідей респондентів щодо недостатнього рівня практичної підготовки, \%

Отже, дослідження показало, що фахівці оцінюють власні рівні підготовки по-різному: добре ознайомленні з теоретичною частиною навчання, але відстають в практичній. Для покращення вище вказаних видів підготовки потрібно вдосконалити навчальні плани, робочі програми з різних дисциплін, підходи до засвоєння знань 3 використанням інтерактивних методик.

Нами також аналізувались відповіді учасників дослідження щодо ї думки про можливі механізми заохочення пацієнтів до активного використання засобів комплексної реабілітації

Більшість опитаних (90\%) вказали, що найкращим способом буде реклама 3 ініціативи самих фізичних терапевтів/реабілітологів; 70\% зазначили, що заохотити пацієнтів можна за допомогою збільшення призначень лікарями засобів реабілітації; тільки 30\% вважають ефективною рекламу в закладах охорони здоров'я. Непокоїть те, що жоден з учасників дослідження не вказав на доцільність поширення інформаційної реклами на рівні держави, що може свідчити про недовіру до державної системи охорони здоров'я в сучасному стані реформування.
Враховуючи стан нормативних документів, які визначають розподіл функцій лікарів фізичної та реабілітаційної медицини та фізичних терапевтів, ми опитали учасників дослідження щодо того, хто, на їх думку, має розробляти комплекс реабілітаційних заходів для пацієнтів: сімейний лікар, лікар фізичної та реабілітаційної медицини чи фізичний терапевт. Половина опитаних вказали, що розробляти і призначати комплекс реабілітаційних заходів повинен саме сімейний лікар, 20\% вважають, що це повинен робити лікар фізичної та реабілітаційної медицини, і $30 \%$ - що сам фізичний терапевт. На нашу думку, у відповідях учасників дослідження розкриваються важливі питання, які повинні бути роз'яснені на рівні нормативних документів. Це набуває особливого значення, оскільки не всі заклади охорони здоров'я повноцінно забезпечені чи будуть забезпечені посадами лікарів фізичної та реабілітаційної медицини. При цьому саме фізичні терапевти та реабілітологи можуть ефективно співпрацювати 3 сімейними лікарями для забезпечення повноцінної та якісної комплексної реабілітації при різних захворюваннях окремих систем організму. 
У продовження попередніх результатів нами було визначено, чи співпрацюють практикуючі фізичні терапевти/реабілітологи з лікарями щодо пацієнтів, яким надають реабілітаційні послуги. Переважна частина (75\%) вказали, що завжди співпрацюють, $15 \%$ зазначили, що дуже рідко, а 10\% - взагалі не співпрацюють.

Перспективи подальших досліджень полягають у розробці практичних рекомендацій щодо покращення рівнів підготовки фізичних терапевтів, їх впровадженні 3 наступним визначенням ефективності.

\section{Висновки}

В результаті дослідження встановлено, що тільки $20 \%$ всіх опитаних фахівців оцінили власний рівень теоретичної підготовки 3 забезпечення комплексної реабілітації в цілому як достатній; $70 \%$ опитаних фахівців оцінили власний рівень теоретичної підготовки як достатній в таких напрямках: забезпечення реабілітації при хворобах кістково-м'язової системи, травмах, пацієнтів 3 різними видами залежностей, після перенесених оперативних втручань на різних органах, особливостей реабілітації дітей та людей похилого віку в амбулаторних умовах. При цьому переважна більшість (70\%) визначила рівень практичної підготовки 3 питань комплексної реабілітації як більш достатній, ніж недостатній, 20\% респондентів вказали, що він більш недостатній, ніж достатній, а 10\% зазначили, що він не достатній.

Враховуючи результати проведеного дослідження, можна зробити загальний висновок, що теоретична та практична підготовка фізичних терапевтів 3 питань комплексної реабілітації цільових груп населення потребує вдосконалення та впровадження сучасних заходів їі покращення.

\section{Література}

1. Гук СВ. Професійні функції фахівця з фізичної реабілітації. Педагогічна освіта: теорія і практика. 2013;14:66-70.

2. Копочинська ЮВ, Дмітрієва НС. Базові компетенції майбутніх фахівців 3 фізичної терапії та ерготерапії у становленні професійної майстерності. Науковий часопис Національного педагогічного університету імені М.П. Драгоманова. Серія № 15 «Науково-педагогічні проблеми фізичної культури (фізична культура і спорт)»: збірник наукових праць. 2019;4(112):51-7.

3. Дуб ММ, Брич ВВ, Грига ММ. Професійні компетентності фізичного терапевта та його асистента як елемент забезпечення реабілітації. Сучасні підходи до формування професійних компетентностей фахівців фізичної терапії та ерготерапії: матеріали науково-практичної конференції з міжнародною участю присвяченої 20-й річниці 3 дня заснування факультету здоров'я та фізичного виховання УжНУ (17-18 жовтня 2019 р., м. Ужгород). Україна. Здоров’я нації. 2019; $2(55): 167$.

4. Дмітрієва НС, Копочинська ЮВ. Наукове обгрунтування застосування інтегративного підходу у підготовці фахівців 3 фізичної терапії. Молодий вчений. 2018;12:420-4.

\section{References}

1. Huk SV. Profesijni funktsii fakhivtsia z fizychnoi reabilitatsii. Pedahohichna osvita: teoriia i praktyka. 2013;14:66-70.

2. Kopochyns'ka YuV, Dmitriieva NS. Bazovi kompetentsii majbutnikh fakhivtsiv z fizychnoi terapii ta erhoterapii u stanovlenni profesijnoi majsternosti. Naukovyj chasopys Natsional'noho pedahohichnoho universytetu imeni M.P. Drahomanova. Seriia № 15 «Naukovo-pedahohichni problemy fizychnoi kul'tury (fizychna kul'tura i sport)»: zbirnyk naukovykh prats'. 2019;4(112):51-7.

3. Dub MM, Brych VV, Hryha MM. Profesijni kompetentnosti fizychnoho terapevta ta joho asystenta iak element zabezpechennia reabilitatsii. Suchasni pidkhody do formuvannia profesijnykh kompetentnostej fakhivtsiv fizychnoi terapii ta erhoterapii: materialy naukovo-praktychnoi konferentsii z mizhnarodnoiu uchastiu prysviachenoi 20-j richnytsi z dnia zasnuvannia fakul'tetu zdorov'ia ta fizychnoho vykhovannia UzhNU (17-18 zhovtnia 2019 r., m. Uzhhorod). Ukraina. Zdorov'ia natsii. 2019; $2(55): 167$.

4. Dmitriieva NS, Kopochyns'ka YuV. Naukove obgruntuvannia zastosuvannia intehratyvnoho pidkhodu u pidhotovtsi fakhivtsiv z fizychnoi terapii. Molodyj vchenyj. 2018;12:420-4.

Дата надходження рукопису до редакції: 11.10 .2019 p.

Мета: проаналізувати рівні теоретичної і практичної підготовки фізичних терапевтів та реабілітологів, які здійснюють професійну діяльність, для забезпечення комплексної реабілітації цільових груп населення.

Матеріали і методи. Системний підхід і системний аналіз; статистичний метод; соціологічний. Соціологічне дослідження охопило 20 фахівців з фізичної терапії та фізичної реабілітації, які займаються професійною діяльністю (кількість респондентів обумовлена малою чисельністю генеральної сукупності цільової групи в регіоні), і проводилося з використанням спеціально розробленого опитувальника.

Результати. В результаті дослідження встановлено, що тільки $20 \%$ всіх опитаних фахівців оцінили власний рівень теоретичної підготовки з забезпечення комплексної реабілітації в цілому як достатній; 70\% опитаних фахівців оцінили 
власний рівень теоретичної підготовки як достатній в таких напрямках: забезпечення реабілітації при хворобах кістковом'язової системи, травмах, пацієнтів з різними видами залежностей, після перенесених оперативних втручань на різних органах, особливостей реабілітації дітей та людей похилого віку в амбулаторних умовах. При цьому переважна більшість (70\%) визначила рівень практичної підготовки з питань комплексної реабілітації як більш достатній, ніж недостатній, 20\% респондентів вказали, що він більш недостатній, ніж достатній, а 10\% зазначили, що він не достатній.

Висновки. Теоретична та практична підготовка фізичних терапевтів 3 питань комплексної реабілітації цільових груп населення. потребує вдосконалення та впровадження сучасних заходів ії покращення.

Ключові слова: фізичний терапевт, реабілітолог, теоретична і практична підготовка, комплексна реабілітація.

Цель: проанализировать уровни теоретической и практической подготовки физических терапевтов и реабилитологов, которые осуществляют профессиональную деятельность, для обеспечения комплексной реабилитации целевых групп населения.

Материалы и методы. Системный подход и системный анализ; статистический метод; социологический. Социологическое исследование охватило 20 специалистов по физической терапии и физической реабилитации, которые занимаются профессиональной деятельностью (количество респондентов обусловлена малой численностью генеральной совокупности целевой группы в регионе), и проводилось с использованием специально разработанного опросника.

Результаты. В результате исследования установлено, что только $20 \%$ всех опрошенных специалистов оценили собственный уровень теоретической подготовки по обеспечению комплексной реабилитации в целом как достаточный; 70\% опрошенных специалистов оценили собственный уровень теоретической подготовки как достаточный в следующих направлениях: обеспечение реабилитации при болезнях костно-мышечной системы, травмах, пациентов с различными видами зависимостей, после перенесенных оперативных вмешательств на различных органах, особенностей реабилитации детей и пожилых людей в амбулаторных условиях. При этом большинство (70\%) определила уровень практической подготовки по вопросам комплексной реабилитации как более достаточный, чем недостаточный, $20 \%$ респондентов указали, что он более недостаточен, чем достаточный, а 10\% отметили, что он не достаточен.

Выводы. Теоретическая и практическая подготовка физических терапевтов по вопросам комплексной реабилитации целевых групп населения. требует совершенствования и внедрения современных мер ее улучшение.

Ключевые слова: физический терапевт, реабилитолог, теоретическая и практическая подготовка, комплексная реабилитация.

Purpose: is to analyse the levels of theoretical and practical training of physical therapists and rehabilitation therapists in order to provide comprehensive rehabilitation of target population groups.

Materials and methods. System approach and system analysis; statistical method; sociological method. The sociological survey included 20 specialists in the field of physical therapy and physical rehabilitation engaged in professional activities (the number of respondents is conditioned by the small size of the general target group in the region) and was conducted using a specially designed questionnaire.

Results. The study found that only $20 \%$ of all surveyed experts rated their own level of theoretical training in providing comprehensive rehabilitation as sufficient; $70 \%$ of the interviewed experts rated their own level of theoretical training as sufficient in the following areas: providing rehabilitation for diseases of the musculoskeletal system, traumas, patients with different types of addictions, after undergoing surgical interventions on different organs, features of rehabilitation of children and the elderly on outpatient basis. At the same time, the vast majority $(70 \%)$ identified the level of practical training on comprehensive rehabilitation as more sufficient, than insufficient; $20 \%$ said that it was more insufficient than sufficient, and $10 \%$ said that it was not sufficient.

Conclusions. Theoretical and practical training of physical therapists on complex rehabilitation of target population groups needs improvement and implementation of modern measures to realize it.

Key words: physical therapist, rehabilitation therapist, theoretical and practical training, comprehensive rehabilitation.

Конфлікт інтересів: відсутній.

Conflicts of interest: authors have no conflicts of interest to declare.

\section{Відомості про авторів}

Брич Валерія Володимирівна - канд.медичних наук, доцент кафедри наук про здоров'я факультету здоров’я та фізичного виховання ДВНЗ «Ужгородський національний університет»; вул. Митна, 29, м. Ужгород, Закарпатська обл., 88000, Україна. +380 (312) 64-38-01, valeria.bruch@uzhnu.edu.ua, ORCID 0000-0003-3741-6002.

Грига Марія Михайлівна - студентка другого року магістратури за спеціальністю 227 «фізична терапія, ерготерапія» факультету здоров’я та фізичного виховання ДВНЗ «Ужгородський національний університет», вул. Митна, 29, м. Ужгород, Закарпатська обл., 88000, Україна.

+380 (312)64-38-01, hruhamasha@gmail.com. 